\title{
ANALYZING TRAVELERS' E-COMPLAINTS: THE CASE OF EGYPTAIR
}

Hossam Samy, Associate Professor,

The Egyptian Higher Ins titute for Tourism and Hotels

\begin{abstract}
The research aims to highlight the concept of online reputation in the airline business and analyze the content of e-complaints posted about Egypt Air via a well-recognized airline quality review and rating site: 'Skytrax'. The primary findings concluded the most criticized service quality elements about Egypt Air on the Internet through a quantitative content analysis technique. It was confirmed that the cabin class, flight route and traveler's area of residence all influence the reviewer's perception towards the negative as pects of the air travel experience. The research proposed an e-complaint handling model with an aim to improve passenger satisfaction and enhance airlines' brand image.
\end{abstract}

Keywords: Content analysis- Egypt Air- Electronic complaints-Passenger satisfaction- Quality review

\section{INTRODUCTION}

\section{Airline quality and customer satisfaction}

The concepts of marketing when applied to transport, as in any other business, means putting the needs of the consumer of transport services first. It is consumers who fill spaces on airplanes, and they will exercise choice by utilizing service which best meet their requirements in terms of price, quality and speed. It is people who are passengers and they will choose the service which most closely matches their idea of value.. People use transport to satisfy other desires than just the thrill of traveling; it is this aspect of transport, more than any other, which must dominate transport marketing philosophy. It is futile designing and operating the best transport service that man can devise in terms of price and comfort, if it does not allow people to satisfy desires other the transport, and if it does not leave or arrive at the right time or in the right place (Samy, 2008).

Beside the cost of the ticket, an airline's potential customers will be influenced by five key product features in making travel decisions and more importantly, in choosing between airlines:

A. The schedule-based features of the services being offered;

B. The comfort-based features

C. In-flight catering

D. Aircraft characteristics

E. ITX (Inclusive tour by scheduled services)

An airline must therefore decide how to combine these various product features to meet customer needs in different markets. This is a complex process because customer requirements will vary not only between different market segments on the same route but also between proximate routes and geographical areas (Samy, 2008).

Air travel has always been classified as one of most intangible service industries. Since the Airline Deregulation Act of 1978, the industry became more concerned than ever with service quality and hence customer satisfaction. Service quality is best defined as the extent to which customer's needs meet or exceed their expectations (Baker, 2013). 


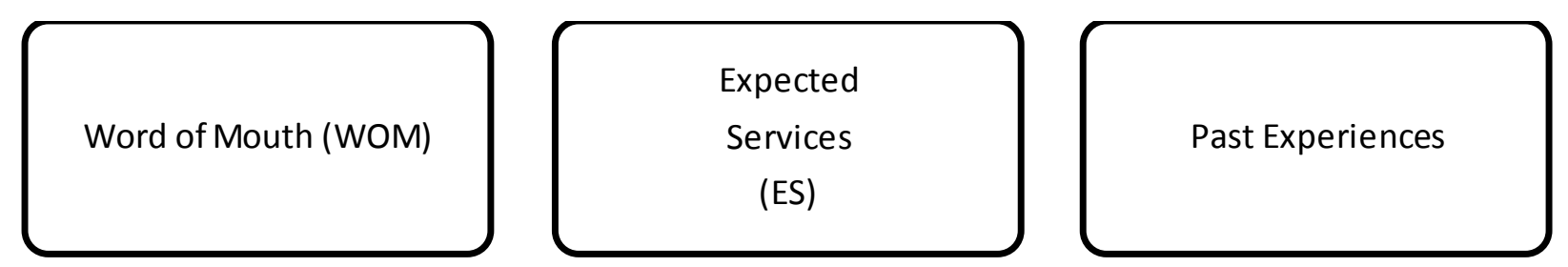

\begin{tabular}{|l|}
\hline Dimensions of Se rvice \\
Quality: \\
-Reliability \\
-Res ponsiveness \\
-Assurance \\
-Empathy \\
-Tangibles \\
\hline
\end{tabular}

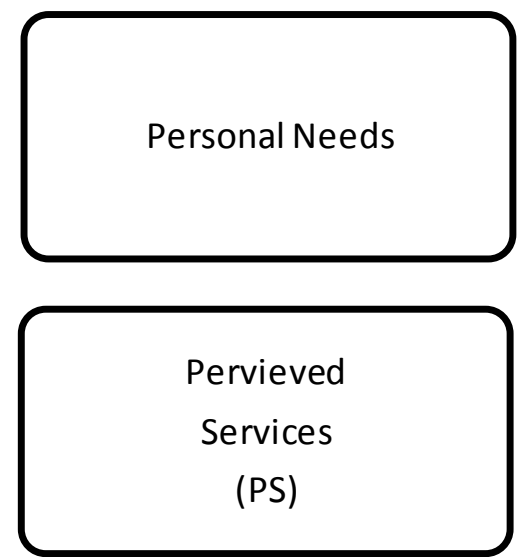
Perceived Service Quality:
1- Expectations exceed
ES $<$ PS (Quality surprise)
2- Expectations met
ES = PS (Satisfactory quality)
3-Expectations not met
ES>PS (Unacceptable quality)

Source: Baker (2013)

Figure 1- Perceived service quality model

Today, customer satisfaction is regarded as a fulfillment response. Fulfillment implies that a consumption goal is recognized. Given the fact that these goals are frequently modified and altered in various ways and directions, consumer researchers began perusing this concept as a whole experience. Satisfaction is a broad concept that includes service quality perception, product quality price, situation factors and personal factors (Baker, 2013).

Since the 90s, the competition created by the free market economy becomes more vigorous over the years and therefore service quality received more attention than ever. Airlines were continuously seeking to provide high quality services and differentiate their products in various ways with an aim to better satisfy consumers (Clemens, 2008). Unlike other travel-related corporations, such as the heterogeneous hospitality sector, air travel is considered as a homogeneous service. The homogeneity of the airline product is considered one of the major negative aspects of the industry, especially in areas of product differentiation and customer satisfaction.

In the US, the Airline Quality Rating (AQR) approach has been successfully employed by the major airlines and by the general public. Over its 26 year history, the Airline Quality Rating has often been cited as an industry standard for comparing airline performance. Currently, the AQR stands as the longest regularly published rating available for airline performance. With the continued global trend in airline operations alliances, the argument becomes even stronger for the Airline Quality Rating to be used as a standard method for comparing the quality of airline performance for international operations as well (Bowen et al, 2016). In the following table, the weight / impact based system is demonstrated with an aim to review the various items taken into consideration when evaluating airline quality. 
Table 1- Airline quality rating weights and impacts

\begin{tabular}{|l|c|c|}
\hline \multicolumn{1}{|c|}{ Crite ria } & Weight & Impact (+/-) \\
\hline (OT) On-time & 8.63 & + \\
\hline (DB) Denied boarding & 8.03 & - \\
\hline (MB) Mis handled baggage & 7.92 & \\
\hline (CC) Customer complaints & 7.17 & \\
Flight Problems & & \\
Over-sales & & \\
Reservations, Ticketing, and Boarding & & \\
Fares & & \\
Refunds & & \\
Baggage & & \\
Customer Service & & \\
Disability & & \\
Advertising & & \\
Discrimination & & \\
Animals & & \\
Other & & \\
\hline
\end{tabular}

Source: Bowen and Headley (2016)

It's important to note that there are many possible aspects that could influence the airline consumers' perception of quality at different times in the consumption process. Generally, an airline passenger is concerned with two basic aspects of the airline service: 1) schedule and 2) price. There are other secondary, but important, aspects that a consumer may consider in the ultimate choice of an airline. The basic factors can be used to explain a large majority of consumer use of airline services.

At the same time, once the basic concerns are met, the larger, more complex set of concerns begin to dominate the consumers perception regarding quality of and satisfaction with a particular service experience and ultimately, the choice of a particular airline. Such things as safety, comfort of the seats, in-flight amenities such as food and beverages, attitude of the ground and flight crew, financial stability of the airline, on-time performance of the flights, assurance that bags arrive with the passengers, crowded conditions of the flight, being bumped from the flight, and frequent flyer programs are important to consumers. Problems arise in a consumer's ability to make meaningful sense from the information available (Samy, 2015).

\section{Online reputation manage ment}

Today, the internet culture represents a paradigm shift for corporate communicators. Organizational success is increasingly dependent on online activities. The information available online about corporations is generally accepted by the business community as a contributing factor in shaping consumer perceptions and opinions of corporations. It's important to note that these perceptions and opinions, regardless of their veracity, have a significant impact on the organization's reputation. Few negative opinions could easily induce waves of criticism against companies. Unfortunately, users have little inclination to assess the expertise or credentials of opinion sources. These commentaries if left unchecked are considered as missed opportunities to strengthen consumer loyalty and improve overall market performance. On the other side, they can wreak havoc on corporate reputation and possibly lead to substantial economic losses (Pak, 2010).

User generated online reviews are gaining continuous credibility in the eyes of consumers and they are currently an essential component of the consumer decision making process. The growing popularity of online review platforms was responsible for creating an intense pressure on corporations to maintain a flawless online reputation. Dealing with negative reviews is challenging because, unlike offline word of mouth (WOM) they persist online and can cause indelible damage to a firm's reputation (Prosperio, 2015).

It's important to note that the airline industry is considered as the most socially devoted business sector in the world. Companies in this field are among the most active in the use of social media (Dijkmas, 2015).

\section{Analyzing e-complaints}

In today's ultracompetitive environment, the pressures of consumer's lower price expectations and the rise of low-cost airlines are driving carriers to awaken to the need to maintain and shape their market 
position. It is essential for airlines to create loyalty beyond price. Airline must focus the brand experience because today's consumers will choose the airline that provides the best overall value. It's important to note that strong airline brands create value for their shareholders when they build emotional connections and influence with consumers and ensure strategy consciousness across the entire company (Ross, 2009).

Analyzing consumer complaints is fundamental in the airline industry. All air carriers recognize that customer satisfaction and the perception of quality is important to the consumer that has a choice of air carriers in any market. With multiple carriers providing the same basic service (transportation from point A to point $\mathrm{B}$ ) the perception of quality held by a consumer has become an important competitive point. To monitor this rather fluid consumer opinion, quality assessment efforts are made periodically by individual airlines and by other consumer interest groups (Samy, 2015). The following figure illustrates the influence of complaint handling on business corporations.

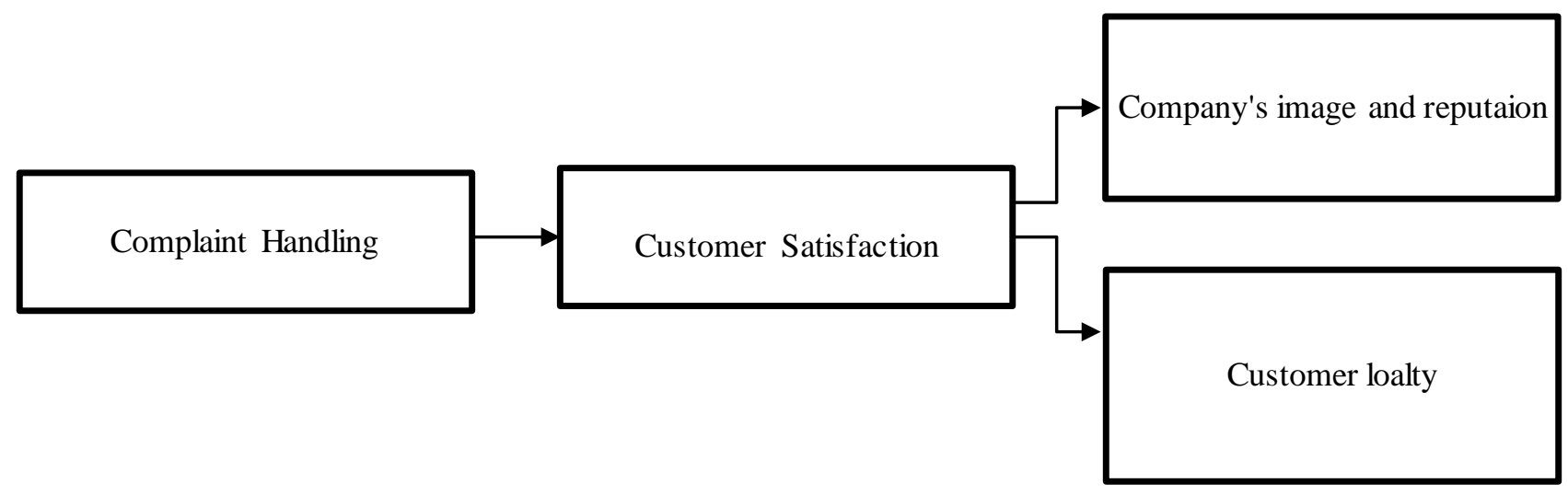

Source: Metwally (2013)

Figure 2- The various impacts of complaint handling

The US department of transportation collects and publishes a report on passenger complaints with major carriers being compared on the basis of number of complaints received per 100.000 passengers carried. Comparing the number of consumer complaints with the number of compliments will provide a first quality control statistic. Airlines must also investigate the nature of complaints they receive. They are a strong indicator of the areas where management attention is needed. The opinions of the airline's own customer contact and sales staff should also be taken into consideration (Shaw, 2007). In the following figure, a model of complaint handling is demonstrated. 


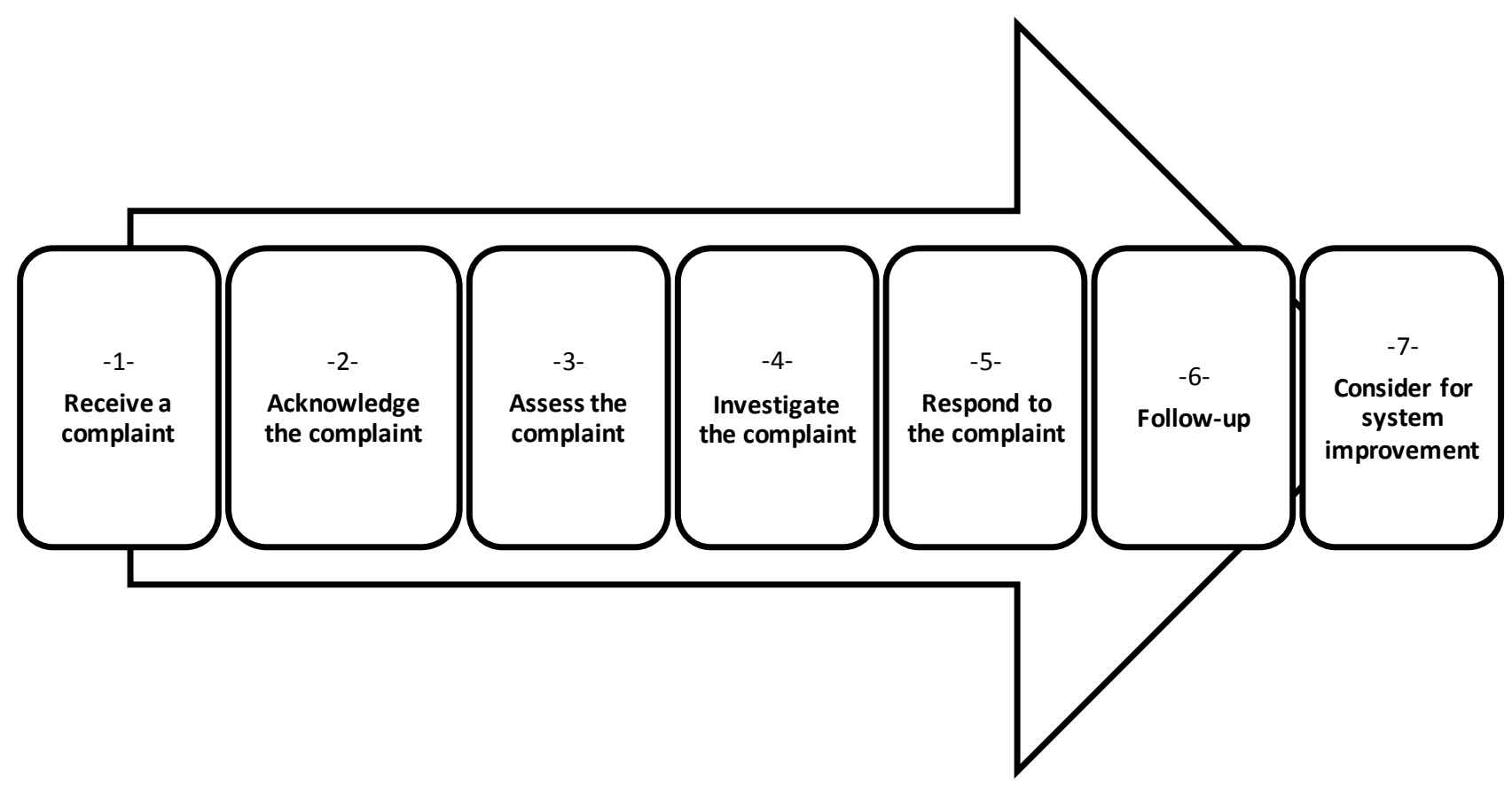

\section{Source: Better practice guide (2009)}

Figure 3 - The complaint handling process

Complaining behavior is defined as: "An act by an individual that involves communicating something negative regarding a product or service." An online negative review can also be defined as: "An expression of dissatisfaction venting emotions, engaging with others, and sharing information" (Lei, 2015 p.1). Online commentary, in general, is defined as a single instance of an author making posting relating to any message through any medium of the Internet (Clark, 2001).

Many studies confirmed that consumer complaint behavior (CCB) is influenced by socio-demographic characteristics of customers, such as gender, age and level of education "(Chiappa, 2012). In an information intensive industry, such as tourism, customers look for advice from their interpersonal relationships and most importantly word of mouth (WOM) channels. These channels are very crucial due to the fact that travel and tourism-related products cannot be easily evaluated without engaging in a first-hand experience. Today, the $\mathrm{e}-\mathrm{WOM}$ is very influential. The e-WOM generating machine is very powerful as it is characterized by the 4Vs: volume, velocity, variety and veracity (means trustworthiness). Given the fact that no travel-related corporations have any control over user generated content, they must carefully monitor online discussion and promptly respond to customer complaints (Lei, 2015).

Consumer review sites give uses the chance to write detailed accounts of their experiences for the primary benefit of other consumers who might be seeking to gather information and/or purchase the same service product or same service category. For marketers and researchers, these online-reviews are a written record of pre-purchase reasoning and post purchase experience from many consumers. The internet comprises millions of electronic 'Fora' such as: discussion boards, message boards, communities, clubs, e-mail groups etc. (Ramaswami, 2003). Complaints were studied from different disciplinary perspectives. Regarding spoken complaints, an important approach analyzes complaint data from a pragmatics perspective that focuses on sematic formulas and discourse strategies with an aim to classify complaints into predefined categories (Vasquez, 2011). Olshtain and Weinbach (1987) originally developed these categories follows: 1- Below the level of reproach (the individual still willing to repeat the experience) 2-dissaproval 3-Complaint 4Accusation and warning 5-Threat. These studies also analyzed other relevant variables such as gender, social status and cultural / ethnic differences.

Another approach relies on ethnomethodology. This approach focuses on generated within ongoing talks both on the personal and professional contexts. These studies tend to rely on methodologies of conversation 
analysis (CA) or discursive psychology. On the other hand, a handful of studies have also examined complaints in written genres. In these studies, the analyses have compared the discourse structure of complaints in different varieties of languages. It's important to note that the number of examined complaints in any form of computer-mediated communication is few (Vasquez, 2011). Content analyses have been used effectively in past investigations of consumer behavior. The primary benefit of content analysis is to help clarify what is being said, in which channel, to whom and with what effect. This method was efficiently applied to marketing research and communication analysis, including a range of consumer 'texts' across different categories of information and product attributes (Ramaswami, 2004).

\section{Egypt Air: company background}

Egypt Air is regarded as a well-established airline in the Arab world. In 1932, it was the first airline to be launched in Africa and the Middle East. The company went through several restructuring phases over the years to finally become a holding company in 2002. In 2008, the airline joined the renowned Star Alliance network. The company owns a number of subsidiary airlines, namely: Air Cairo and Egypt air Express. The airline benefits from a relative monopoly over Cairo International Airport. The airline plans to expand its current flight from 81 to 127 aircrafts in the upcoming years. It's important to note that the air carrier suffers from a number of economic problems: 1- Overstaffed labor 2-The airline load factor is moderate (63\%) 3Airline losses reached EGP10 billion in the fiscal year 2014/ 2015 (Egypt Air, 2016 a). It's clear from the in the following table (no.2), that Skytrax (airline quality rating) dropped Egypt air from its top Middle East airline quality ratings of 2015 .

Table 2- The best quality airlines in the Middle East-2015

\begin{tabular}{|c|l|}
\hline Ranking & Airline \\
\hline $\mathbf{1}$ & Qatar Airways \\
\hline $\mathbf{2}$ & Emirates \\
\hline $\mathbf{3}$ & Etihad Airways \\
\hline $\mathbf{4}$ & Oman Air \\
\hline $\mathbf{5}$ & Saudi Airlines \\
\hline $\mathbf{6}$ & Gulf Air \\
\hline $\mathbf{7}$ & Royal Jordanian Airlines \\
\hline $\mathbf{8}$ & Air Arabia \\
\hline $\mathbf{9}$ & Fly Dubai \\
\hline $\mathbf{1 0}$ & MEA \\
\hline
\end{tabular}

\section{Source: Skytrax (2016)}

According to online consumer reviews, Skytrax (2016) gave Egypt air a 3-star airline quality rating and describes the current status of Egypt air as follows:

"Egypt air is delivering a fair quality performance that conforms to an industry average of acceptable product and service standards. The 3-Star Airline rating signifies a satisfactory standard of core product for most travel categories, but it also reflects some inconsistency amongst either standards of front-line staff Service or product delivery for the cabin service and their home-base airport environments".

The World Travel Awards (considered the hallmark of quality travel worldwide) did not recognize Egypt air in any of its award categories in the Middle East region. Since the year 2000, Emirates airlines, Qatar airways, Gulf air and Etihad Airways dominated all the airline quality awards in all categories (World Air Travel Awards, 2016).

\section{Complaint handling in Egyptair}

Customer complaints play a vital role in evaluating the airline's service quality standards. There a two types of customer complaints in the airline industry: 1- complaints over controlled aspects of the airline service 2-complaints over uncontrolled aspects (e.g. weather conditions). Airlines tend to suffer from numerous cases of service disruption, such as: flight-related (delay-cancellation-overbooking) - baggage miss-handling (delay-loss-damage) - negative attitude of on-ground / in-flight staff). Having a complaint handling policy is fundamental for the improvement of the airline's service quality standards (Upadhyaya, 
2012). In the following table, Egypt air's official customer service plan regarding complaint handling is demonstrated.

Table 3- Egypt air's customer service plan in times of service disruption

\begin{tabular}{|c|c|}
\hline Complaint case & Tactical handling plan \\
\hline Flight de lay / cance llation & $\begin{array}{l}\text { - Provide an alternative flight to reach the } \\
\text { destination and possibly extend the air ticket } \\
\text { validity (without any extra charges). } \\
\text { - Additional remedies include: compensations, } \\
\text { refreshments, accommodation and other } \\
\text { reimbursements (if applicable by law). }\end{array}$ \\
\hline Baggage delay, loss and damage & $\begin{array}{l}\text { - The airline compensates passengers in cases of } \\
\text { baggage delay, loss or damage (this is valid after all } \\
\text { reasonable measures were taken to avoid the delay } \\
\text { or it was impossible to take such measures). } \\
\text { Complaint must be filed within } 21 \text { days in case of } \\
\text { delayed baggage and } 7 \text { days in case of damage. }\end{array}$ \\
\hline Overbooked flights & $\begin{array}{l}\text { Compensations and the opportunity to fly on an } \\
\text { alternative are offered to passengers. }\end{array}$ \\
\hline
\end{tabular}

Source: Egyptair (2016 b)

Metwally (2013) assessed the passenger complaint handling process in Egyptair, and concluded that it was inefficient. The main causes of such inefficiency are explained in the following table.

Table 4- The defects in Egypt air's complaint handling mechanism

\begin{tabular}{|l|l|}
\hline \multicolumn{1}{|c|}{ Defect } & \multicolumn{1}{c|}{ Description } \\
\hline $\begin{array}{l}\text { A lack of top management commitment to } \\
\text { effective handling of customer complaints }\end{array}$ & $\begin{array}{l}\text {-The absence of an effective organizational } \\
\text { philosophy that values customer complaints } \\
\text {-The airline does not have a well-defined strategy } \\
\text { that includes a set of clear procedures and rules of } \\
\text { passenger complaint handling. }\end{array}$ \\
\hline A reactive approach to complaints handling & $\begin{array}{l}\text {-The airline seeks to handle customer complaints } \\
\text { instantly but does not seek to analyze the roots of } \\
\text { the defects. } \\
\text {-Complaint handling in Egyptair is not a strategic } \\
\text { tool that aims to improve service quality. }\end{array}$ \\
\hline Poor communication & $\begin{array}{l}\text {-Many complaints require the cooperation between } \\
\text { various levels and departments in order to proper } \\
\text { handle the case. Poor communication between } \\
\text { various organizational levels slows down the pace } \\
\text { of complaint handling and eventually effective } \\
\text { passenger communication. }\end{array}$ \\
\hline
\end{tabular}




\section{METHODOLOGY}

\section{Research objectives}

1- Highlight the concepts of airline service quality and online reputation

2-Understand the distinctive nature of airline-complaints

3- Analyze and test the relationship between several aspects of the air travel experience (namely: flight route- cabin class- passengers' area of residence) and the type e-complaint.

4- Analyze the content of Egypt air customer reviews

5- Define the most commonly voiced negative experiences about Egypt air on the chosen customer review site: Skytrax.

\section{Content analysis}

This research aims to analyze the content of complaints posted on 'Skytrax' about Egyptair. The analysis results will help managers to further improve the airline's level of services and its online corporate image. Since 1999, the Skytrax website is the leading international airline rating system classifying airlines by the quality of front line products and staff service. "World airline star ratings" are recognized as a global benchmark of airline standards. This airline review website (www.airlinequality.com) was chosen as the source of Egypt Air's e-complaints. This is due to the website's reputation and most importantly its influence on air travelers worldwide. The site is very reliable as it is an independent customer forum with no financial association with any organization.

The population consisted of all online reviewers posting negative complaints about Egypt air services within the time frame of the research (April, 2010- July, 2016). Total enumeration of available negative reviews about Egypt Air was gathered from the Skytrax site (353 negative reviews). The complaint elements or variables were determined according to a detailed review of all negative comments posted on the above mentioned site.

The reviews were coded to extract the negative sentiments expressed in each post. 'Aquad v.7' (a renowned computer assisted quantitative data analysis software) was used to perform a quantitative content analysis of all gathered reviews with an aim to categorize all mentioned negative elements according to the predefined airline experience elements. The ANOVA test was conducted on SPSS v.22.0 to identify whether there are any significant differences in consumer evaluations based on respondent's country of origin, flight route and cabin class. The paper seeks to propose an analysis model for airline managers with an aim to interpret ecomplaints.

\section{RESULTS AND DISCUSSION \\ Descriptive statistics}

The most common airline experience elements were predefined according to the following categories: 1Catering 2-In-flight entertainment 3-Seating comfort 4-Customer service 5-Amenities 6-On-time departure / arrival 7-Baggage handling. The cabin class was divided into: 1- Economy class 2-Business class (the first class reviews were unavailable). The traveler's region of residence was categorized as follows: 1-America 2Europe 3-Africa 4-Middle East 5-Asia. As for the flight routes, they were classified according to the following: 1-Transatlantic 2-Intercontinental 3-Regional 4-Domestic. In the following table, a description of the gathered data is demonstrated according to various predefined categories.

Table 5- Descriptive statistics results of flight information

\begin{tabular}{|l|c|l|c|l|c|}
\hline \multicolumn{1}{c|}{$\begin{array}{c}\text { Cabin } \\
\text { Class }\end{array}$} & $\mathbf{( \% )}$ & \multicolumn{1}{|c|}{ Flight route } & $\mathbf{( \% )}$ & \multicolumn{1}{|c|}{$\begin{array}{c}\text { Traveler's area of } \\
\text { residence }\end{array}$} & $\mathbf{( \% )}$ \\
\hline Economy & 71.1 & Transatlantic & 14.7 & America & 21.8 \\
\hline \multirow{2}{*}{ Business } & 28.8 & Intercontinental & 75.3 & Europe & 50.9 \\
\cline { 3 - 6 } & & Regional & 4.8 & Africa & 5 \\
\cline { 3 - 6 } & & Domestic & 5 & Middle East & 7.36 \\
\cline { 4 - 6 } & & & Asia & 14.7 \\
\hline
\end{tabular}

It's clear from the previous table that the majority of respondents were economy class travelers $(71.1 \%)$ and most of the flights were classified as intercontinental flights (75.3\%). 50.9\% of respondents were residing in Europe followed by America (21.8\%).

\section{Content analysis results}

The customer service is ranked as the most complained about element $(29.7 \%)$, followed by the catering $(17.2 \%)$, as shown in the following figure. 


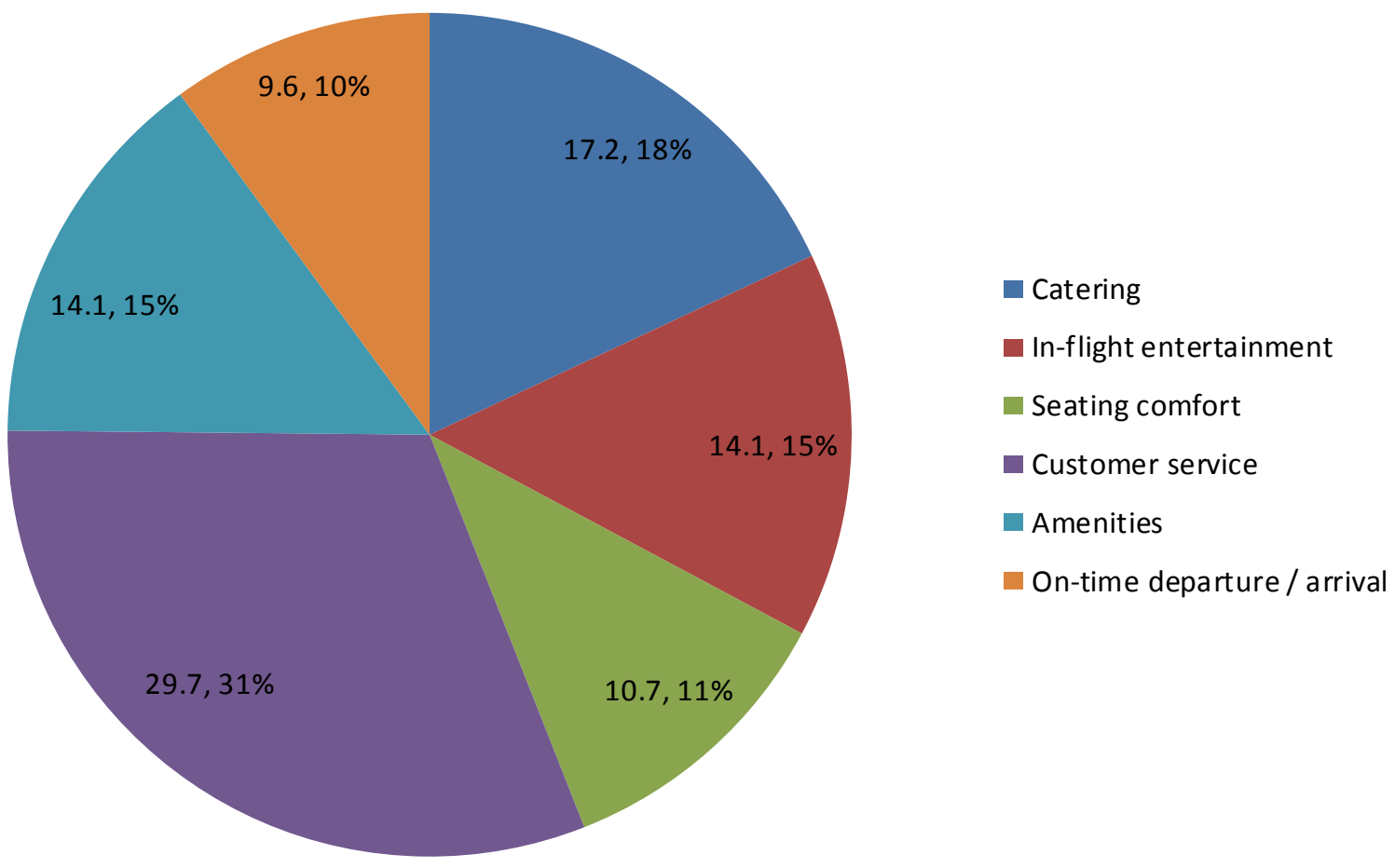

Figure 4- Respondent's E-complaints by category

The following table ranks various complaints according to their category. All review posts were analyzed and classified according to the predefined criteria.

Table 5-The ranking of the most posted e-complaints by category *

\begin{tabular}{|c|l|c|c|}
\hline Ranking & \multicolumn{1}{|c|}{ Complaint element } & Frequency & $(\%)$ \\
\hline 1 & Customer service & 105 & 29.7 \\
\hline 2 & Catering & 60 & 16.9 \\
\hline 3 & Amenities & 51 & 14.4 \\
\hline 4 & In-flight entertainment & 50 & 14.1 \\
\hline 5 & Seating comfort & 38 & 10.7 \\
\hline 6 & On-time departure / arrival & 34 & 9.6 \\
\hline 7 & Baggage handling & 15 & 4.2 \\
\hline Total & 353 & 100 \\
\hline
\end{tabular}

Source: * Results are generated by Aquad (CAQDAS)

The previous ranking reflects the most complained about areas of Egypt Air's air travel experience. Each negative complaint category harms the online reputation of the company until resolved by the management. It's clear that the customer service, which involves the human input of the company, is generating many online negative comments about the company.

\section{Qualitative overview of e-complaint data}

The majority of respondents were complaining about customer service quality of Egypt Air, especially during times of flight disruption. A number of passengers complained about the cabin staff's lack of enthusiasm or care during various flights. Some others stated the staff is somewhat inattentive and absent during the majority of the flying hours. Extra services or inquiries are not welcomed by many cabin staff members. The catering was described as unimaginative and average by many respondents. Egypt Air still has 
a number of outdated aircrafts among its fleet where the passenger amenities are not contemporary enough comparing to other Star Alliance airlines. This was very apparent in the in-flight entertainment devices and the facilities offered in the business class cabins. It's important to note that being a member of the alliance does put an extra burden on Egypt Air regarding its image and performance. Many reviewers compare between Egypt Air and other Star Alliance members in terms of service quality. The in-flight entertainment was described by many as undiversified, especially regarding the movies section. It's clear that passengers need better convertible seats in the business class cabin during long-haul flights. The on-time departure arrival was among the least complained about elements on the quality site. Still, the customer service of airport personnel could surely better handle any delays by informing passengers in real time and providing necessary assistance and consulting services to unsatisfied travelers. Baggage handling did not occur largely among complaints but the handling of lost baggage is described as another area that lacks effective communication with passengers.

\section{ANOVA test results}

The ANOVA test was used to find out whether cabin class type, fight route and traveler's region of residence influence the type of complaint posted on the quality review site under investigation

Table 6- ANOVA test results for complaint elements by cabin clas s, flight route and passenge r's are a of residence.

\begin{tabular}{|c|c|c|c|c|c|c|c|}
\hline Attributes & $\begin{array}{l}\text { Source of } \\
\text { Variation }\end{array}$ & $S S$ & $d . f$. & $M S$ & $F$ & $P$-value & F crit. \\
\hline \multirow[t]{3}{*}{ Cabin class } & Between Groups & 1585.786 & 1 & 1585.786 & \multirow[t]{3}{*}{5.836225} & \multirow[t]{3}{*}{0.032565} & \multirow[t]{3}{*}{4.747225} \\
\hline & Within Groups & 3260.571 & 12 & \multirow[t]{2}{*}{271.7143} & & & \\
\hline & Total & 4846.357 & 13 & & & & \\
\hline \multirow[t]{3}{*}{ Flight route } & Between Groups & 6131.536 & 3 & 2043.845 & \multirow[t]{3}{*}{18.97469} & \multirow[t]{3}{*}{$1.59 \mathrm{E}-06$} & \multirow[t]{3}{*}{3.008787} \\
\hline & Within Groups & 2585.143 & 24 & \multirow[t]{2}{*}{107.7143} & & & \\
\hline & Total & 8716.679 & 27 & & & & \\
\hline \multirow{3}{*}{$\begin{array}{l}\text { Area of } \\
\text { residence }\end{array}$} & Between Groups & 2444.457 & 4 & 611.1143 & \multirow[t]{3}{*}{11.04233} & \multirow[t]{3}{*}{$1.26 \mathrm{E}-05$} & \multirow[t]{3}{*}{2.689628} \\
\hline & Within Groups & 1660.286 & 30 & \multirow[t]{2}{*}{55.34286} & & & \\
\hline & Total & 4104.743 & 34 & & & & \\
\hline
\end{tabular}

Results of the ANOVA test showed that $\mathrm{F}(1.12)=5.83$ at $\mathrm{p}=0.03$. The test confirms $\mathrm{F}>\mathrm{F}$ crit. (5.836>4.747), therefore there is a significant difference between the respondents with respect to complaint category by cabin class. This result assures that the traveler's choice of cabin class on Egypt air flights influences their choice of complaint elements. The ANOVA test results showed that F (3.24) $=18.97$. The test confirms F > F crit. (18.974>3.008), therefore there is a difference between the respondents with respect to complaint category by flight route. This result confirms that complaint areas are influenced by the traveler's flight route on the Egypt Air network. The test results also show that F (4.30) =11.04. The test confirms F > F crit. (11.042>2.689), therefore there is a difference between the respondents with respect to complaint category by area of residence. Therefore, it is confirmed that that travelers' area of residence influences their perception towards service quality and thus their area of complaint.

\section{CONCLUSION}

Online reputation management has become a fundamental discipline in the airline industry, especially after the spread of the internet culture throughout the world. Effective handling of e-complaints will have a positive influence on passenger satisfaction, which will eventually influence the airline's brand image and online reputation. Egypt air is currently not among the leading Arab airlines in terms of service quality ratings. The company holds an average quality rating on the most influential online review site for the airline industry: Skytrax. The content analysis of e-complaints on the aforementioned site proved that the customer service was ranked as the most complained about element of the air travel experience on Egypt Air (105 complaints). The results assure that this particular element is associated with many other aspects of airline 
services and it could damage the online reputation of the company's brand, especially that air travel is considered primary as a service product that largely relies on the human input. It is confirmed that the perception of negative air travel elements, which included customer service, catering, passenger amenities, inflight-entertainment, seating comfort, punctuality and baggage handling, differ according to passengers' cabin class, flight route and area of residence.

\section{RECOMMENDATIONS}

-Egypt Air can improve its brand image by monitoring and evaluating e-complaints on the internet, as they are today more harmful than traditional complaints.

- Forming an effective content analysis model will surely help the airline respond to various negative reviews and hence improve its service quality standards over time.

-Enhancing the customer service sector will surely improve the overall quality of the airline. More effective training is needed on so many levels in order to meet high quality standards in terms of behavior, customer care and communication

-Airline e-complaint models should adopt a multi-segment approach to classify e-complaint according to the previously mentioned criteria. This classification will help managers close any service quality gaps more accurately according to various subcategories of complaints.

-An effective e-complaint analysis system will help the carrier tailor more personalized flying experiences for passengers and most importantly listen to their impressions regarding the airline's image and quality standards.

-Improving the company's ratings on 'Skytrax', among other airline quality related authorities is crucial for the airline's survival in this ultra-competitive environment.

- A proposed computer-assisted content analysis model for handling airline e-complaints: 


\section{1-Receiving e-complaints}

- Acknowledging the complaints

- Recording the complaints with a unique identifier code

- Acquiring initial relevant supporting data: date of complaint-passenger profile -scheduleflight route-type of operation- cabin clas s

$\downarrow$

\section{2-Coding and clas sifying data}

- Coding the textual material of the e-complaints according to various criteria

- Classifying codes into airline service quality categories

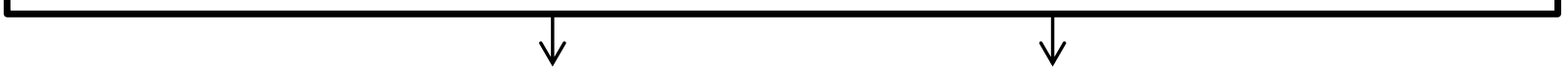

\section{3-Content analysis}

- Using a computer-assisted content analysis software to analyze the data

\begin{tabular}{|c|c|}
\hline 4-Result assessment & $\downarrow$ \\
$\bullet$ & Identifying the areas of complaints \\
$\bullet$ & Determine the frequency of occurrence of complaint elements \\
$\bullet$ & Assess weight/ impact of complaint elements according to passenger expectations \\
& $\downarrow$ \\
\hline
\end{tabular}

\section{5-Inves tigation}

- Investigate all the relevant circumstances and information surrounding complaints

- Explore the roots of the problem through people, departments, airports and market segments

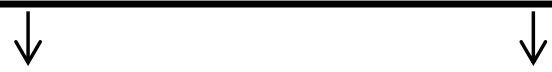

\section{6-Response}

- Provide a feedback regarding the complaint status to the passenger

- Resolve immediately in case of urgency

- Provide remedies (if they are in compliance to the airline regulations and policies)

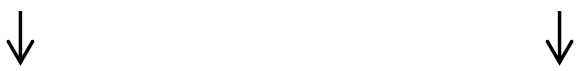

7-System improvement

- Improving the system to prevent the problem from re-occurring again (depends upon the severity, weight and seriousness of the complaint)

Figure 5-Content analysis model for airline e-complaints 


\section{REFRENCES}

Anna Aero (2013). Egypt Air struggles to fully recover: launches four new destinations this week including Manchester and Toronto, [Internet], retrieved from: http:/www.anna.aero/2013/06/05/egyptair-struggles-to-fully-recover, [Accessed in the $9^{\text {th }}$ of June, 2016].

Better Practice Guide 1 (2009), Better Practice Guide to Complaint Handling, Australia: Commonwealth Ombudsman.

Baker, D. (2013). Service quality and customer satisfaction in the airline industry: a competition between legacy airlines and low-cost airlines, American journal of tourism research, Vol.2 (1), pp67-77.

Bowen, B. and Headley, D. (2016). Airline quality rating, 2016. US: Wichita state university.

Clark, A. (2001). They're talking about you: some thoughts about managing online commentary affecting corporate reputation, Journal of Communication Management, Vol. 5(3), pp. 262-276.

Clemens, M. et.al. (2008).An empirical analysis of customer satisfaction in international air travel, Innovative marketing, vol. 4(2), pp.49-62

Dijkmas, C., et.al. (2015). Online conversation and corporate reputation: a two wave longitudinal study on the effects of exposure to the social media activities of a highly interactive company, Journal of computer-mediated communication, Vol. 20, pp.632-648.

Egypt Air (2008).Annual report, 2016, Cairo: Egypt Air airlines

Egypt Air (2016a).Annual report, 2016, Cairo: Egypt Air airlines

Egypt Air (2016b). Egypt air customer service plan, Cairo: Egypt Air airlines

Khafagi, A. (2015). The civil aviation losses ten billion pounds after the January revolution, radio and television magazine, $21^{\text {st }}$ Mar. [Internet], retrieved from: www.maspiro.net. [Accessed in the $10^{\text {th }}$ of June, 2016]

Lei, S. and Law, S. (2015). Content analysis of Trip Advisor reviews on restaurants: a case study of Macau, Journal of Tourism, Vol. 16 (1), pp.17-28.

Olshtain, E. and Weinbach, L. (1987). Complaints: A study of speech act behavior among native and non-native speakers of Hebrew. In J. Verschueren and M. Bertucelli-Papi (Eds.). The Pragmatic Perspective (pp. 195-208). Amsterdam: John Benjamins.

Pak, C. (2010). Emergent practice in online corporate reputation management. Applied information management, University of Oregon.

Prosperio, D. and Zervas, G. (2015). Online reputation management: estimating the impact of management responses on consumer reviews. In: proceedings of the sixteenth ACM conference on economics and computation, Portland, June, 2015, New York: Sigecom, pp. 79-122.

Ramaswami, S. and Varghese, S. (2003). Reading the voice of customer: a content analysis of consumer reviews, Institutional knowledge, Singapore Management University.

Ross, P. (2009). Building brand value and influence in the airline industry, London: Reed publishing services.

Samy, H. (2008). The economics of low-cost airline and its impact on tourism demand. Unpublished $(\mathrm{PhD})$, Faculty of tourism and hotels, Helwan University.

Samy, H. (2015). Strategies for competitive marketing, Cairo: Egypt Air airlines.

Saw, S. (2007). Airline marketing and management, $6^{\text {th }}$ ed., UK: Ashgate.

Skytrax (2016). Egypt Air customer reviews, [Internet], retrieved from: www.airlinequality.com/airline-reviews/egyptair. [Accessed in the 10th of May, 2016]

Upadhyaya, M. (2012). Customer satisfaction measurement in airline services: an empirical study of need: gap analysis, International Journal of Management and Strategy, Vol. 3 (5).

World travel awards (2016). The best airlines in the world by global region, [Internet], retrieved from: www.worldtravelawards.com, [Accessed in the $11^{\text {th }}$ of April, 2016] 


\section{تحليل الثكاوى الإكترونية للمسافرين:دراسة حالة شركة مصر للطيران}

الملخص العربى

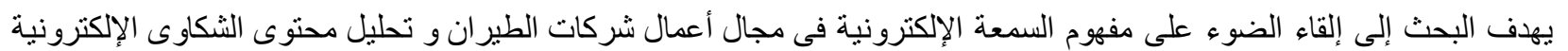

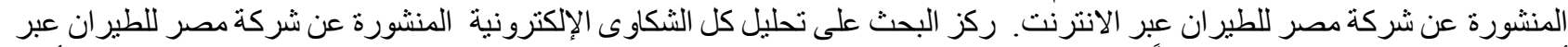

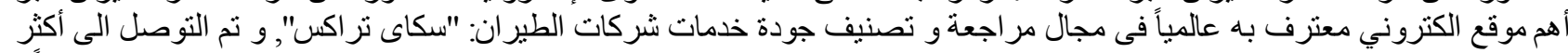

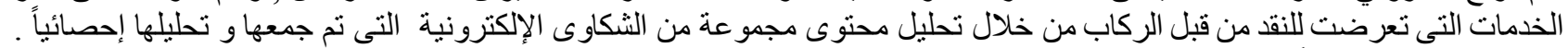

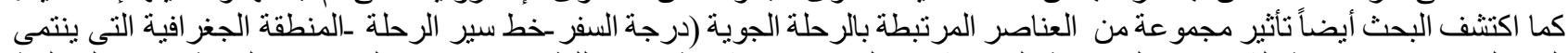

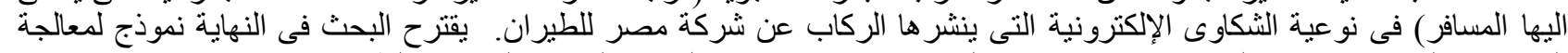

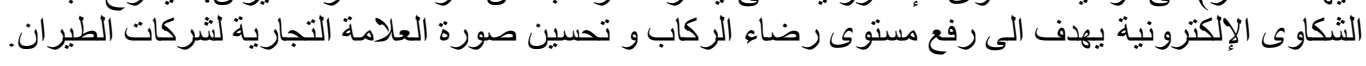

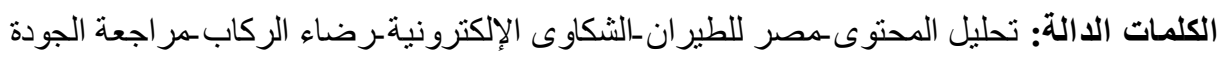

